\title{
The development and proliferation of the trophoblast from ectopic mouse embryo allografts of increasing gestational age
}

\author{
C. V. Hunt and G. B. Avery \\ Department of Biochemistry, Research Foundation of Children's Hospital, \\ National Medical Center, Washington, D.C. 20009, U.S.A.
}

\begin{abstract}
Summary. The development and proliferation of trophoblast from ectopic mouse embryo allografts and isografts of increasing gestational age in nonimmune and specifically preimmunized hosts was studied. Specific preimmunization of recipients

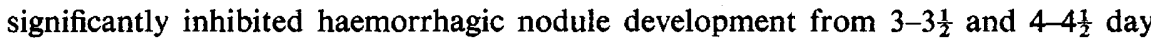

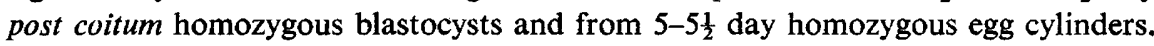
Preimmunization had no effect on the percentage of haemorrhagic nodules which

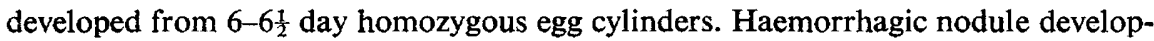
ment was significantly increased for $F_{1}$ hybrid allografts compared to homozygous allografts to preimmunized recipients. Coincident with the immune inhibition of haemorrhagic nodule formation was the microscopic finding that in some cases trophoblast cells developed without subsequent proliferation in preimmunized hosts.

The results are discussed in relation to the expression of transplantation antigens by the developing conceptus, the continued differentiation of the embryo after transplantation, and the inductive influences of the inner cell mass on trophoblast ontogeny.
\end{abstract}

\section{Introduction}

The mammalian fetus is a potential allograft to the mother. It contains genetic information from the father and therefore has the potential for expressing transplantation antigens which the mother could recognize as being foreign. However, despite the expression of histocompatibility antigens by the fetus (Simmons \& Russell, 1962; Edidin, 1964; Schlesinger, 1964; Seigler \& Metzgar, 1970; Patthey \& Edidin, 1973), there is no conclusive evidence that the fetus in utero can be rejected as an allograft by maternal immunocytes.

It has been suggested that there is a physiological immune barrier between the mother and the fetus to prevent allograft rejection of the fetus (Medawar, 1953). This immunological buffer zone is apparently comprised of trophoblast, a tissue of fetal origin, which forms a continuous boundary between the maternal and fetal placental components. Simmons \& Russell $(1962,1966)$ found that preimplantation mouse zygotes were subject to immune destruction as ectopic allografts in specifically preimmunized recipients. The ectoplacental cone trophoblast tissue, however, was not destroyed as an allograft in similar recipients.

Kirby, Billington \& James (1966) observed that while $3 \frac{1}{2}$-day post coitum (p.c.) preimplantation mouse blastocysts failed to grow ectopically as allografts in specifically hyperimmunized pseudopregnant female hosts, some blastocysts underwent implantation and developed normally when transferred to the uterine horns of the same recipients. Kirby et al. felt that the uterus must therefore act as an immunologically privileged site before and during implantation and that the decidua protected the implanting blastocyst from immune destruction until the trophoblast developed and assumed its role as an immunological buffer zone. Kirby et al. (1966) postulated that the trophoblast did not become an effective barrier until 6 days p.c., when a continuous pericellular coating (Kirby, Billington, Bradbury \& Goldstein, 1964; Bradbury, Billington \& Kirby, 1965) could be detected between the trophoblast and the decidual cells. 
Beer, Billingham \& Hoerr (1971) evaluated the ability of the pregnant and nonpregnant rat uterus to mediate transplantation immunity and concluded that the decidual tissue of the pregnant uterus could only interfere with the development of the host's immunological response. It was not capable of affording protection to grafts against a pre-existing state of sensitivity.

It has not been established in previous reports at what point during the implantation process trophoblastic tissue is first able to differentiate and proliferate in an immune environment outside the influences of the internal milieu of the uterus. The present report investigated this question in the mouse by the ectopic transplantation of embryo allografts of increasing gestational age to recipients preimmunized to various degrees against donor transplantation antigens.

\section{Materials and Methods}

\section{Animals}

Inbred mice were obtained from Jackson Laboratories or Microbiological Associates. The following strains were used: $\mathrm{C} 3 \mathrm{H} / \mathrm{HeJ}\left(\mathrm{H}-2^{k}, \mathrm{H}-3^{\mathrm{b}}\right)$ and $\mathrm{C} 57 \mathrm{BL} / 6 \mathrm{mai}\left(\mathrm{H}-2^{\mathrm{b}}, \mathrm{H}-3^{\mathrm{a}}\right)$. The mice were 8-9 weeks old when received and were used within 2 months.

Recipients. Recipients of ectopic kidney capsule grafts were C57BL/6 males which were allocated to three groups: nonimmune, immune, and hyperimmune. The immune animals were presensitized with two consecutive orthotopic skin grafts of full thickness from $\mathrm{C} 3 \mathrm{H}$ donors. The hyperimmune animals were presensitized with two consecutive skin grafts plus 5-7 weekly i.p. injections of $30-50 \times 10^{6}$ viable spleen cells. Spleen cell suspensions were prepared by mechanical dissociation of donor spleens in phosphate-buffered saline (PBS, pH 7.4). The preimmunized mice were used within 1 month after the last skin graft or spleen cell injection.

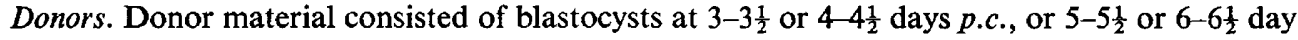
whole egg cylinders. Homozygous material was obtained from intrastrain $\mathrm{C} 3 \mathrm{H}$ or $\mathrm{C} 57$ matings. Interstrain material was obtained from $(\mathrm{C} 57 \times \mathrm{C} 3 \mathrm{H}) \mathrm{F}_{1}$ hybrids. Animals were paired during a 12-hr dark cycle beginning at 20.00 hours and observed for vaginal plugs the following morning. The presence of a vaginal plug was taken as Day 0 of pregnancy.

Blastocysts were obtained by flushing excised uterine horns with PBS. At $4-4 \frac{1}{2}$ days p.c., only

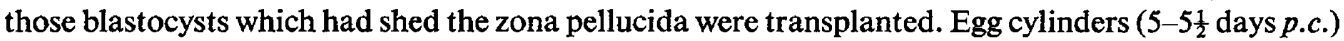
were removed as follows. The excised uterine horns were first divided into individual implantation sites, and then each implantation site was opened along the mesometrial border. The cut edges were retracted, exposing the decidual swelling. The uppermost layers of decidua were removed with iridectomy knives and teased gently until the implanting egg cylinder was located. The whole embryo was then freed of surrounding decidual cells and stored briefly in PBS until transplanted. At 6-6 $\frac{1}{2}$ days, the egg cylinder was removed by opening individual implantation sites along the antimesometrial border and dissecting out the whole embryo from the implantation chamber. In both cases, extreme care was taken in removing any adherent decidual tissue to avoid damaging the embryo and surrounding trophectoderm and/or trophoblast. Microscopic examination of serially sectioned specimens indicated that little, if any, damage occurred to the trophectoderm and/or trophoblast layer. Few, if any, decidual cells were found adherent to the transplants.

\section{Transplantation}

Recipient mice were anaesthetized with sodium pentobarbital and the kidney exposed through a flank incision with the aid of a dissecting microscope, and a small incision was made in the kidney capsule. One blastocyst or egg cylinder was inserted beneath the kidney capsule with a hand-drawn Pasteur pipette attached to a blow tube. A graft was placed in both kidneys of each recipient.

\section{Analysis of results}

Recipient mice were killed 7 days after transplantation. The kidneys were removed and examined 
macroscopically for the presence of a haemorrhagic nodule indicative of trophoblastic proliferation. In addition, kidneys without haemorrhagic nodules were examined under a dissecting microscope for evidence of graft development. All positive kidneys were biopsied.

Biopsy specimens were fixed in Carnoy's or Clark's solution, embedded in paraffin wax, serially sectioned at $7 \mu \mathrm{m}$, and stained with haematoxylin and eosin. The graft sites were microscopically examined for the presence of viable and nonviable trophoblast cells, blood lake formation, inner cell mass or inner cell mass derivatives, and cellular infiltration. An estimate of the amount of viable trophoblast, nonviable trophoblast, and cellular infiltration was obtained by subjectively grading grafts for each of these characteristics on a scale of 0 (absent) to plus 4.

Statistical analysis of results was by means of the $\chi^{2}$ test.

\section{Results}

\section{Homozygous allografts}

The results of transplanting homozygous embryo allografts of increasing gestational age beneath the kidney capsules of nonimmune and preimmunized recipients are recorded in Table 1. In Exp. 1 macroscopic haemorrhagic nodules developed from virtually all allografts transplanted beneath the kidney capsules of nonimmune recipients. Microscopically the nodules consisted of numerous trophoblastic giant cells, extensive blood lake formation, and evidence of inner cell mass development which usually appeared in the form of extraembryonic membranes. There was little evidence of cellular infiltration by mononuclear and polymorphonuclear leucocytes indicative of the lack of an allograft rejection response.

Table 1. The results of transplanting $\mathrm{C} 3 \mathrm{H} \times \mathrm{C} 3 \mathrm{H}$ mouse blastocyst or egg cylinder allografts beneath the kidney capsules of $\mathrm{C} 57 \mathrm{BL} / 6$ recipients

\begin{tabular}{|c|c|c|c|c|c|c|c|}
\hline \multirow{2}{*}{$\begin{array}{c}\text { Exp. } \\
\text { no. }\end{array}$} & \multirow{2}{*}{$\begin{array}{l}\text { Blastocyst or egg } \\
\text { cylinder age } \\
\text { (days post coitum) }\end{array}$} & \multirow{2}{*}{$\begin{array}{c}\text { Recipient } \\
\text { preimmunization }\end{array}$} & \multirow{2}{*}{$\begin{array}{l}\text { Total } \\
\text { no. of } \\
\text { grafts }\end{array}$} & \multicolumn{2}{|c|}{$\begin{array}{l}\text { Graft sites with } \\
\text { trophoblast cells plus } \\
\text { haemorrhagic nodule }\end{array}$} & \multicolumn{2}{|c|}{$\begin{array}{l}\text { Graft sites with } \\
\text { trophoblast cells but no } \\
\text { haemorrhagic nodule }\end{array}$} \\
\hline & & & & No. & $\%$ & No. & $\%$ \\
\hline 1. A & $3-3 \frac{1}{2}$ & None & 28 & 28 & 100 & 0 & $\mathbf{0}$ \\
\hline B & $4-4 \frac{1}{2}$ & & 20 & 20 & 100 & 0 & $\mathbf{0}$ \\
\hline C & $5-5 \frac{1}{2}$ & & 20 & 19 & 95 & $\mathbf{0}$ & $\mathbf{0}$ \\
\hline $\mathbf{D}$ & $6-6 \frac{1}{2}$ & & 18 & 18 & 100 & 0 & 0 \\
\hline 2. $\mathrm{A}$ & $3-3 \frac{1}{2}$ & $2 \mathrm{C} 3 \mathrm{H}$ skin grafts & 30 & 3 & 10 & 4 & 13 \\
\hline $\mathbf{B}$ & $4-4 \frac{1}{2}$ & & 32 & 13 & 41 & 4 & 13 \\
\hline $\mathrm{C}$ & $5-5 \frac{1}{2}$ & & 30 & 15 & 50 & 6 & 20 \\
\hline $\mathbf{D}$ & $6-6 \frac{1}{2}$ & & 18 & 18 & 100 & 0 & $\mathbf{0}$ \\
\hline 3. $\mathbf{A}$ & $3-3 \frac{1}{2}$ & $2 \mathrm{C} 3 \mathrm{H}$ skin grafts $+5-7$ & 24 & 0 & 0 & 0 & 0 \\
\hline B & $4-4 \frac{1}{2}$ & spleen injections & 24 & 0 & 0 & 0 & 0 \\
\hline C & $5-5 \frac{1}{2}$ & & 28 & 12 & 43 & 0 & 0 \\
\hline D & $6-6 \frac{1}{2}$ & & 18 & 18 & 100 & 0 & 0 \\
\hline
\end{tabular}

Significant differences: Exp. 2A versus Exp. 1A, $P<0.001$; Exp. 2B versus Exp. 1B, $P<0 \cdot 001$; Exp. 2C versus Exp. 1C, $P<0.01$; Exp. 3C versus Exp. 1C, $P<0.001$; Exp. 3 C versus Exp. 3B, $P<0.001$.

In Exp. 2 preimmunization of $\mathrm{C} 57$ recipients with two $\mathrm{C} 3 \mathrm{H}$ skin grafts significantly inhibited development of haemorrhagic nodules in all age groups except 6-61-day egg cylinders. There was, however, an increase in the percentage of macroscopic nodules which developed as the gestational age of the donor material increased. Coincident with the inhibition of macroscopic haemorrhagic nodule formation was the microscopic finding of trophoblastic cell development without prolifera-

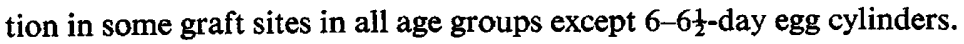

In Exp. 3 there was complete inhibition of macroscopic nodule development from 3-31- and 


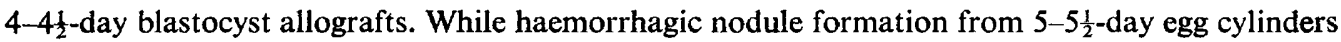
was also significantly inhibited, the percentage of macroscopic haemorrhagic nodules which did develop was significantly greater than for the younger allografts. The degree of recipient preimmunization had no statistically significant effect on the percentage of macroscopic haemorrhagic

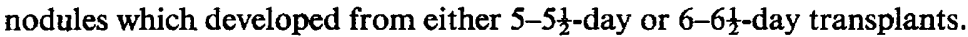

The majority of haemorrhagic nodules in mice in Exps 2 and 3 were microscopically similar in appearance to the transplants to nonimmune recipients except for the presence of cellular infiltration. A mild to heavy infiltration of mononuclear and polymorphonuclear cells was found in the kidney bed tissue surrounding the graft site and usually extended into the margins of the graft. The majority of nodules contained large numbers of viable trophoblast cells, even though the trophoblast cells were often surrounded by numerous lymphocytes at the graft margins. In contrast, in those graft sites which contained trophoblast cells that had not proliferated to form a macroscopic haemorrhagic

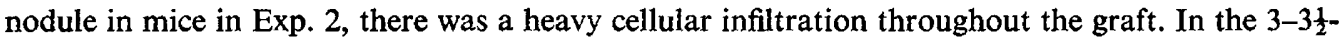
and 4-41 -day donor groups, the trophoblast cells were few in number and all nonviable in appearance.

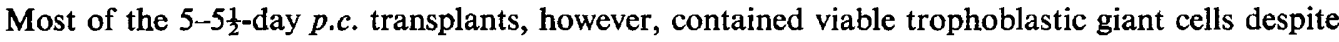
the presence of a heavy cellular infiltration.

As a control against nonspecific effects, another series of experiments was performed in which C57 recipients were preimmunized with $\mathrm{C} 3 \mathrm{H}$ skin grafts alone or with the addition of spleen cells. There was no inhibitory or suppressive effect on trophoblast development and proliferation from C57 homozygous blastocyst or egg cylinder isografts similar in age to the $\mathrm{C} 3 \mathrm{H}$ homozygous allografts, indicating that the inhibition of trophoblast development and the suppression of trophoblast proliferation were associated with specific preimmunization of recipients against donor alloantigens.

\section{Hybrid allografts}

Comparison of the results of Exps 4 and 5 (Table 2) with those of Exps 1-3 indicates that haemorrhagic nodule development was significantly increased for all hybrid allografts compared with homozygous blastocyst and egg cylinder allografts of similar age. For example, pre-hyperimmuniza-

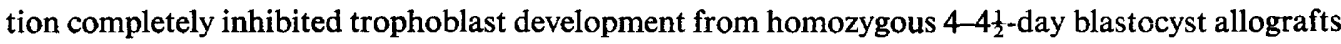
while over $50 \%$ of hybrid transplants developed haemorrhagic nodules.

Table 2. Results of transplanting $(\mathrm{C} 57 \times \mathrm{C} 3 \mathrm{H}) \mathrm{F}_{1}$ mouse blastocyst or egg cylinder allografts beneath the kidney capsules of preimmunized $\mathrm{C} 57 \mathrm{BL} / 6$ recipients

\begin{tabular}{|c|c|c|c|c|c|c|c|}
\hline \multirow{2}{*}{$\begin{array}{l}\text { Exp. } \\
\text { no. }\end{array}$} & \multirow{2}{*}{$\begin{array}{l}\text { Blastocyst or egg } \\
\text { cylinder age } \\
\text { (days post coitum) }\end{array}$} & \multirow{2}{*}{$\begin{array}{c}\text { Recipient } \\
\text { preimmunization }\end{array}$} & \multirow{2}{*}{$\begin{array}{l}\text { Total } \\
\text { no. of } \\
\text { grafts }\end{array}$} & \multicolumn{2}{|c|}{$\begin{array}{l}\text { Graft sites with } \\
\text { trophoblast cells plus } \\
\text { haemorrhagic nodule }\end{array}$} & \multicolumn{2}{|c|}{$\begin{array}{l}\text { Graft sites with } \\
\text { trophoblast cells but no } \\
\text { haemorrhagic nodule }\end{array}$} \\
\hline & & & & No. & $\%$ & No. & $\%$ \\
\hline 4. $\mathbf{A}$ & $4-4 \frac{1}{2}$ & $2 \mathrm{C} 3 \mathrm{H}$ skin grafts & 28 & 19 & 68 & 2 & 7 \\
\hline B & $5-5 \frac{1}{2}$ & & 24 & 19 & 79 & 3 & 13 \\
\hline 5. $\mathrm{A}$ & $4-4 \frac{1}{2}$ & $2 \mathrm{C} 3 \mathrm{H}$ skin grafts $+5-7$ & 26 & 14 & 54 & 0 & 0 \\
\hline B & $5-5 \frac{1}{2}$ & spleen cell injections & 26 & 21 & 81 & 1 & 4 \\
\hline
\end{tabular}

Significant differences: Exp. 4A versus Exp. 2B, $P<0 \cdot 05$; Exp. 4B versus Exp. 2C, $P<0.05$; Exp. 4B versus Exp. 2D, $P<0.05$; Exp. 5A versus Exp. 3B, $P<0.05$; Exp. 5B versus Exp. $3 C, P<0.01$; Exp. 5B versus Exp. $3 D, P<0.05$.

\section{Intermediate host allografts}

The results of Exps 6 and 7 (Table 3) further suggest that trophoblastic cell development and proliferation from ectopic embryo allografts when there is pre-existing immunity is dependent upon the attainment of a certain level of embryonic differentiation before transplantation. Homozygous C3H 4-41-day blastocyst allografts were transplanted beneath the kidney capsules of nonimmune C57 recipients. After 1 or 2 days, the primary recipients were killed, the grafts removed and retransplanted beneath the kidney capsules of secondary recipients pre-hyperimmunized to $\mathrm{C} 3 \mathrm{H}$ 
alloantigens, and the secondary recipients killed after 7 days. The development of $4-4 \frac{1}{2}$-day blastocyst allografts for only $24 \mathrm{hr}$ in a nonimmune recipient significantly increased the percentage of haemorrhagic nodules which developed in pre-hyperimmunized hosts. After $48 \mathrm{hr}$ in a nonimmune primary recipient, re-transplantation resulted in haemorrhagic nodule development from virtually all transplants.

Table 3. Results of ectopic re-transplantation of 4-41-day $\mathrm{C} 3 \mathrm{H} \times \mathrm{C} 3 \mathrm{H}$ mouse blastocyst allografts to preimmunized C57BL/6 recipients. Primary recipients were nonimmune C57BL/6 mice

\begin{tabular}{|c|c|c|c|c|c|c|c|}
\hline \multirow{2}{*}{$\begin{array}{l}\text { Exp. } \\
\text { no. }\end{array}$} & \multirow{2}{*}{$\begin{array}{c}\text { Primary graft } \\
\text { age at } \\
\text { re-transplantation }\end{array}$} & \multirow{2}{*}{$\begin{array}{l}\text { Secondary } \\
\text { recipient } \\
\text { preimmunization }\end{array}$} & \multirow{2}{*}{$\begin{array}{l}\text { Total } \\
\text { no. of } \\
\text { grafts }\end{array}$} & \multicolumn{2}{|c|}{$\begin{array}{l}\text { Graft sites with } \\
\text { trophoblast cells plus } \\
\text { haemorrhagic nodule }\end{array}$} & \multicolumn{2}{|c|}{$\begin{array}{l}\text { Graft sites with } \\
\text { trophoblast cells but no } \\
\text { haemorrhagic nodule }\end{array}$} \\
\hline & & & & No. & $\%$ & No. & $\%$ \\
\hline 6. A & $\begin{array}{l}+1 \text { day } \\
+2 \text { day }\end{array}$ & $\begin{array}{l}2 \text { C3H skin grafts }+5-7 \\
\text { spleen cell injections }\end{array}$ & $\begin{array}{l}18 \\
14\end{array}$ & $\begin{array}{r}9 \\
13\end{array}$ & $\begin{array}{l}50 \\
93\end{array}$ & $\begin{array}{l}1 \\
0\end{array}$ & $\begin{array}{l}6 \\
0\end{array}$ \\
\hline 7. $\mathrm{A}$ & +1 day & None & 12 & 12 & 100 & 0 & 0 \\
\hline
\end{tabular}

Significant differences: Exp. 6A versus Exp. 3B, $P<0.001$; Exp. 6B versus Exp. $6 \mathrm{~A}, P<0.05$.

\section{Discussion}

As expected from previous studies, the inhibition of trophoblastic development or proliferation from ectopic mouse embryo allografts in the present study appeared to be an immunological phenomenon. It occurred only in recipients which had been specifically preimmunized against the transplantation antigens of the donor strain. Isografts to similar recipients exhibited neither significant inhibition of trophoblast development or proliferation nor significant microscopic evidence of an allograft rejection response. It is still unclear, however, what are the relative roles of cellular and humoral immunity in this model system. Vandeputte \& Sobis (1972) were able to adoptively transfer the immunity against trophoblastic development from ectopic blastocysts with sensitized lymphoid cells but not with immune serum. In a similar study, James \& Yoshida (1972) found a diminution in haemorrhagic nodule volume and a significant reduction in trophoblast cell nuclei after adoptive transfer of immunocytes to secondary hosts. However, exposure of zona-free blastocysts in vitro to immune serum plus heterologous complement and their subsequent ectopic transplantation inhibited trophoblast development (James, 1969; James \& Yoshida, 1972).

It is unclear at the present time whether the inhibition of trophoblast development from ectopic allografts in preimmunized recipients is the result of a direct immune response against the pretrophoblastic trophectoderm or the indirect result of a rejection of the inner cell mass. The inhibition of trophoblast development from ectopic blastocyst allografts in preimmunized recipients has been attributed to the presence of transplantation antigens on the trophectoderm. While preimplantation mouse blastocysts do not appear to express $\mathbf{H}-2$ alloantigens on the trophectoderm, they do express some non-H-2 transplantation antigens (Palm, Heyner \& Brinster, 1971). It has also been shown that inhibition of trophoblast development from ectopic mouse blastocyst allografts can occur across donor-recipient combinations which differ solely in non-H-2 alloantigens but not in those differing solely in H-2 (Searle, Johnson, Billington, Elson \& Cutterbuck-Jackson, 1974).

It has been suggested that the inhibition of trophoblast development and proliferation in ectopic blastocyst allografts can be explained as an immune rejection of the inner cell mass or its derivatives which are a necessary inductive influence for normal trophoblast ontogeny (Gardner, Johnson \& Edwards, 1973). Gardner (1972) found evidence from intrauterine transplants of mouse blastocyst trophectoderm and/or inner cell mass tissue to indicate that the presence of the latter was critical for trophoblast proliferation. In the absence of the inner cell mass, the trophectoderm gave rise to small numbers of primary trophoblastic giant cells which did not proliferate. These observations were also supported by studies of trophoblast development and proliferation from ectopic mouse blastocyst isografts in the presence or absence of concomitant inner cell mass development (Johnson, 1972). 
There is evidence that $\mathbf{H}-2$ alloantigens are first expressed on the mouse embryo devoid of trophoblast at Day 7 of gestation (Patthey \& Edidin, 1973), a stage when the embryo is subject to immune rejection both as an ectopic allograft and by immune lymphocytes in vitro (Jenkinson \& Billington, 1974). However, the extent of non-H-2 or low level H-2 alloantigen expression by the inner cell mass or its derivatives before this stage of gestation has not been established.

One of the factors which determines the extent of ectopic trophoblast development and proliferation is the interaction between timing of the immune response of the recipient and the amount of embryonic differentiation which can take place before a rejection response. The differences in the extent of trophoblast development associated with the degree of recipient preimmunization which we found (Table 2) indicates that there was differentiation of the transplant in recipients preimmunized with two skin grafts before the host mounted a significant immune rejection response. Searle et al. (1974) found that a marked cellular infiltration associated with an allograft rejection appears in a pre-hyperimmunized host $48-72 \mathrm{hr}$ after an ectopic blastocyst allograft. A longer response interval would be expected after a lesser degree of preimmunization and would allow more time for embryonic differentiation to continue.

Another factor involved in the ectopic development and proliferation of the trophoblast appears to be the level of antigen expression by the transplant. In the present study, evidence was found which indicated that ectopic hybrid allografts were more resistant than homozygous allografts of comparable gestational age to an immune inhibition of trophoblast development. Simmons \& Russell (1966) first reported that a significantly greater percentage of haemorrhagic nodules developed in preimmunized recipients from ectopic allografts of tubal eggs of hybrid mice compared to similar homozygous allografts, and suggested that this was due to a gene-dose effect on transplantation antigen expression in hybrid embryos.

Our finding that there was no microscopic evidence of trophoblast development in many preimmunized recipient, nonhaemorrhagic graft sites could be interpreted as indicating the direct immune rejection of the trophectoderm. However, the presence of primary trophoblastic giant cells which had not undergone proliferation in recipients preimmunized with two skin grafts is similar to the observations of Gardner (1972) and Johnson (1972). Microscopic examination of these grafts revealed an intense cellular infiltration throughout the entire graft. Since ectopic allografts of pure trophoblast are not associated with cellular infiltration in preimmunized hosts (Simmons \& Russell, 1966), the finding of infiltration suggests an immune response to other embryonic tissues in the transplant. This immune suppression of trophoblast proliferation may represent the arrest of trophoblast ontogeny as a result of immune rejection of the inner cell mass.

The results of the present study indicate that the earliest stage of mouse trophoblast ontogeny at which the trophoblast can continue to develop and proliferate when transplanted to an ectopic pre-hyperimmunized environment, i.e. before a rejection response, is not reached until the last stage

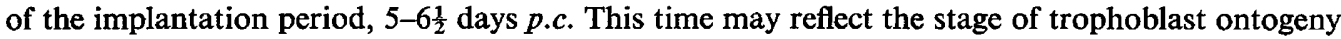
at which the inductive influences of the inner cell mass are no longer necessary or can take place before immune rejection of the inner cell mass or its dissolution in an ectopic environment. Our studies would seem to support the contention of Kirby et al. (1966) that the uterine milieu may provide an as yet undefined protective influence against a maternal allograft rejection of the conceptus before and during implantation.

We thank Mr Edward Riggs, Mrs Joyce Hobbs, Mrs Mabel Wilks, and Mr Keil Mah for their help with the histology. This work was supported by Grant FR-00284 from the National Institutes of Health.

\section{References}

Beer, A.E., Billingham, R.E. \& Hoerr, R.A. (1971) Elicitation and expression of transplantation immunity in the uterus. Transplant. Proc. 3, 609611.
Bradbury, S., Billington, W.D. \& KirbY, D.R.S. (1965) A histochemical and electron microscopical study of the fibrinoid of the mouse placenta. $J$. $R$. microsc. Soc. 84, 199-211. 
EDIDIN, M. (1964) Transplantation antigens in the mouse embryo. The fate of early embryo tissues transplanted to adult hosts. J. Embryol. exp. Morph. 12, 309-316.

GARDNER, R.L. (1972) An investigation of inner cell mass and trophoblast tissues following their isolation from the mouse blastocyst. J. Embryol. exp. Morph. 28, 279-312.

Gardner, R.L., Johnson, M.H. \& EdwaRds, R.G. (1973) Are $\mathrm{H}_{2}$ antigens expressed in the preimplantation blastocyst? In Immunology of Reproduction, pp. 480-488. Eds K. Bratanov, R. G. Edwards, V. H. Vulcharov, V. Dikov \& B. Somley. Bulgaria's Academy of Science Press, Sofia.

JAMES, D.A. (1969) Antigenicity of the blastocyst masked by the zona pellucida. Transplantation 8 , 846-851.

JAMES, D.A. \& YoshidA, S.M. (1972) Blastocyst elicited immunity: failure to demonstrate immunological characteristics in mice. $J$. Reprod. Fert. 31, 337339.

Jenkinson, E.J. \& Billington, W.D. (1974) Differential susceptibility of mouse trophoblast and embryonic tissue to immune cell lysis. Transplantation 18, 286-289.

Johnson, M.H. (1972) Relationship between inner cell mass derivatives and trophoblast proliferation in ectopic pregnancy. J. Embryol. exp. Morph. 28, 306-312.

Kirby, D.R.S., Billington, W.D., Bradbury, S. \& GoldSTEIN, D.J. (1964) Antigen barrier of the mouse placenta. Nature, Lond. 204, 548-549.

KIRBY, D.R.S., BILlingtoN, W.D. \& JAMES, D.A. (1966)
Transplantation of eggs to the kidney and uterus of immunized mice. Transplantation 4, 713-718.

Medawar, P.B. (1953) Some immunological and endocrinological problems raised by the evolution of viviparity in vertebrates. In Evolution, Symp. Soc. exp. Biol., No. 7, pp. 320-338. Eds J. F. Danielli \& R. Brown. Academic Press, New York and London.

Palm, J., Heyner, S. \& Brinster, R.L. (1971) Differential immunofluorescence of fertilized mouse eggs with $\mathrm{H}-2$ and non-H-2 antibody. J. exp. Med. 133, 12821293.

Patthey, H. \& Edidin, M. (1973) Evidence for the time of appearance of $\mathrm{H}-2$ antigens in mouse development. Transplantation 15, 211-214.

SChlesinger, M. (1964) Serologic studies of embryonic and trophoblast tissues of the mouse. Immunology 93, 255-263.

Searle, R.F., Johnson, M.H., Billington, W.D., Elson, J. \& CUTterbuCK-JACKson, S. (1974) Investigation of $\mathrm{H}-2$ and non-H-2 antigens on the mouse blastocyst. Transplantation 18, 136-141.

Seigler, H.F. \& Metzgar, R.D. (1970) Embryonic development of human transplantation antigens. Transplantation 9, 478-486.

Simmons, R.L. \& RuSSELL, P.S. (1962) The antigenicity of mouse trophoblast. Ann. N.Y. Acad. Sci.99, 717-732.

Simmons, R.L. \& Russell, P.S. (1966) The histocompatibility antigens of fertilized mouse eggs and trophoblast. Ann. N.Y. Acad. Sci. 129, 35-45.

VANDEPUTte, M. \& SobIs, H. (1972) Histocompatibility antigens on mouse blastocysts and ectoplacental cones. Transplantation 14, 331-338.

Received 30 May 1975 